\title{
Monitoring the Environment Exposed to Road Waste
}

\author{
Vitaliy V. Chelnokov ${ }^{1}$, Aleksey V. Matasov ${ }^{1}$, Elena Zabolotnaya ${ }^{1,2^{*}}$, Anna S. \\ Makarova ${ }^{1}$, Andrey N. Glushko ${ }^{3}$ \\ ${ }^{1}$ D. Mendeleev University of Chemical Technology of Russia \\ 2 JSC "Fine Chemicals R\&D Centre" \\ ${ }^{3} \mathrm{SIC}$ Kurchatov Institute - IREA \\ ORCID
}

Zabolotnaya Elena; 0000-0002-5461-5145

Corresponding Author:

Zabolotnaya Elena; email:

zabolotnaya.e@inbox.ru

Dates

Published 13 January 2022

Publishing services provided by

Knowledge E

(c) Vitaliy V.Chelnokov et al. This article is distributed under the terms of the Creative Commons Attribution License, which permits unrestricted use and redistribution provided that the original author and source are credited.

Selection and Peer-review under the responsibility of the 8th Scientific and Practical Conference Conference Committee.
Abstract. This study aimed to carry out a systematic analysis of the literature on the environmental impactsof waste resulting from year-round maintenance of roads (WMR) with deicing agents. The impacts on economic factors and the environment at all stages of the life cycle were systematically examined, taking into account the engineering and technological efficiencies, and the direct, indirect, prolonged and deferred effects. A structural-integral block-hierarchical model for monitoring and evaluating the impacts of WMR on the environment and on the industrial, social and economic system as a whole was developed.This incorporated the complex spatial-temporal industrial, biological, physical and chemical impacts of elements of the road infrastructure itself, as well as external conditions.

Keywords: pollution monitoring, environmental impact of waste, pollution from transport

\section{Introduction}

Investigation of the environmental-socio-economic consequences of the use of agents for the maintenance of economic objects is associated with the study as criteria environmental standards, and assessments of the balanced development of economic systems.

Determination of criteria for environmental regulation and assessment balanced development of economic systems is one of the least studied and priority issues of both economics and ecology.

\section{Methodology}

For the first time, a multi-level structure for analytical monitoring and assessment of environmental impacts of WMR was developed (Fig. 1) by an intelligent information CALSsystem, in which, based on system research, impact indicators were allocated to a cluster architecture in the relationship of each of them with the appropriate analytical control methods and analytical equipment. The architecture for computer control of intellectual 


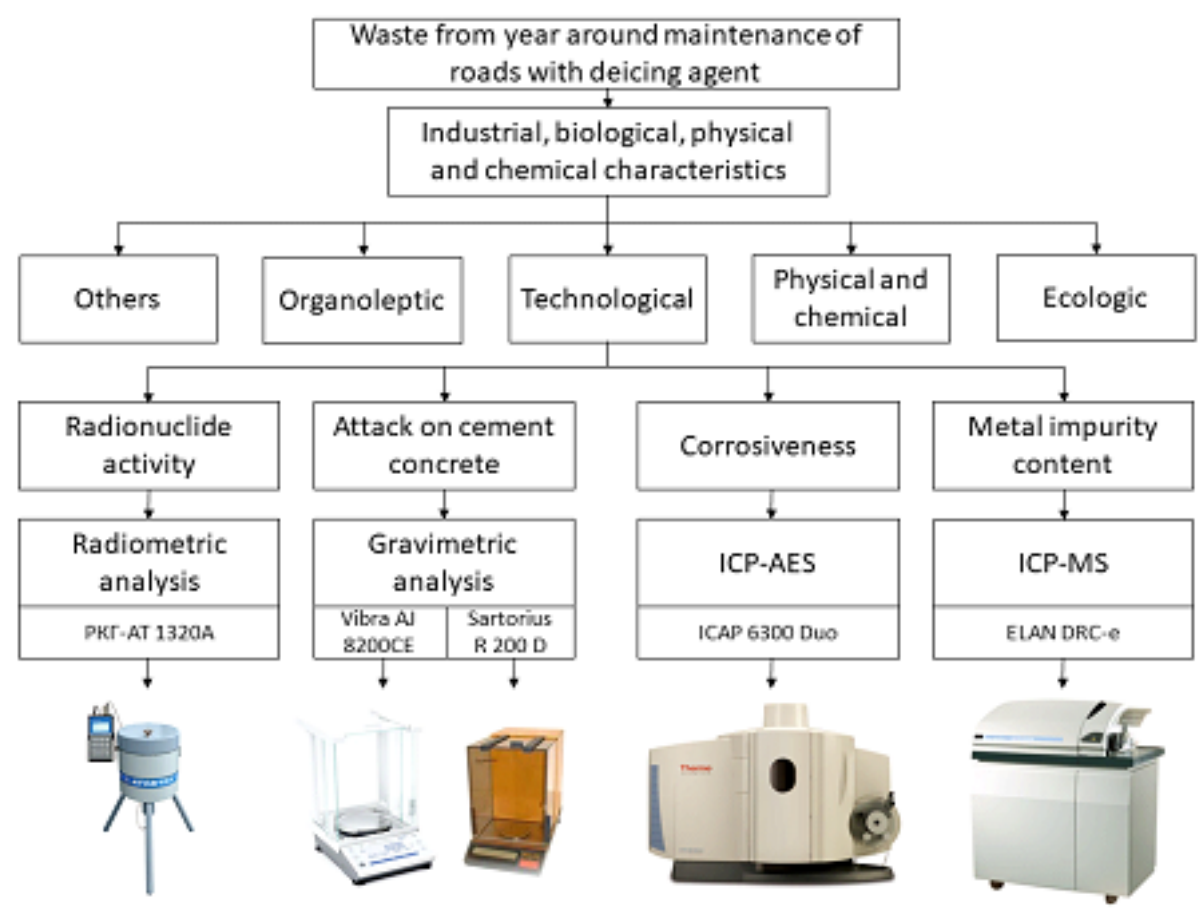

Figure 1: Structure of monitoring and assessment of environmental WMRimpacts.

information in the following information sections was developed: industrial, biological, physical and chemical impactindicators; methods of analysis; analytical equipment [1]. Each of the factor-forming components of the WMR included in the system is evaluated by a number of indicators, grouped into four subcategories: organoleptic (appearance, color, smell, etc.), physical and chemical (mass fraction of soluble salts, grain composition, mass fraction of insoluble substances in water, hydrogen index, density, dynamic viscosity, etc.), technological (hygroscopy, slumping) and environmental (corrosiveness on metal, aggressive effect on cement concrete, activity of natural radionuclides, content of chemical substances (including heavy metals), etc.) [2].

\section{Experimental}

The analysis and description of the chemicals properties that are dangerous for the environment (including flora and fauna) and human health, which are part of agents for the maintenance of roads, was carried out. In the performance of the set of research works, the content of chemicals included in road maintenance agents in environmental objects was assessed, taking into account their migration and transformation in the environment (example in Table 1) [3]. 
TABLE 1: The content of pollutants depending on the distance from the road transport complex.

\begin{tabular}{|c|c|c|c|c|c|}
\hline Characteristic & $\begin{array}{l}\text { Road } \\
\text { puddle }\end{array}$ & Road snow & $\begin{array}{l}\text { Snow, } 5 \text { meters } \\
\text { from the road }\end{array}$ & $\begin{array}{l}\text { Snow, } 20 \text { meters } \\
\text { from the road }\end{array}$ & Dynamic \\
\hline $\begin{array}{l}\text { Weight percentage of } \\
\text { suspended substance, } \%\end{array}$ & 1 & 0,3 & 0,04 & $<0,01$ & \\
\hline $\begin{array}{l}\text { Weight percentage of } \\
\text { sodium chloride, } \%\end{array}$ & 0,87 & 0,21 & 0,013 & 0,0037 & \\
\hline $\begin{array}{l}\text { Weight percentage of } \\
\text { calcium chloride, } \%\end{array}$ & 0,28 & 0,06 & 0,0075 & 0,0022 & \\
\hline $\begin{array}{l}\text { Weight percentage } \\
\text { potassium chloride, } \%\end{array}$ & 0,002 & 0,0011 & 0,0001 & $<0,0001$ & \\
\hline $\begin{array}{l}\text { Zink (gross content), } \\
\mathrm{mg} / \mathrm{kg}\end{array}$ & 1,7 & 1,4 & 0,53 & $<5$ & \\
\hline $\begin{array}{l}\text { Nickel } \\
\text { content),mg/kg }\end{array}$ & 0,1 & 0,1 & 0,06 & $<2$ & \\
\hline $\begin{array}{l}\text { Copper (gross content), } \\
\mathrm{mg} / \mathrm{kg}\end{array}$ & 0,42 & 0,36 & 0,13 & $<2$ & \\
\hline $\begin{array}{l}\text { Cobalt } \\
\text { content),mg/kg }\end{array}$ & 0,06 & 0,05 & 0,02 & $<0,5$ & \\
\hline $\begin{array}{l}\text { Chromium } \\
\text { content),mg/kg }\end{array}$ & 0,13 & 0,12 & 0,04 & $<5$ & \\
\hline $\begin{array}{l}\begin{array}{l}\text { Selenium } \\
\text { content),mg/kg }\end{array} \quad \text { (gross }\end{array}$ & $<0,05$ & $<0,05$ & $<0,05$ & $<0,5$ & \\
\hline $\begin{array}{l}\text { Lead (gross content), } \\
\mathrm{mg} / \mathrm{kg}\end{array}$ & 0,03 & 0,09 & 0,03 & $<1$ & \\
\hline $\begin{array}{ll}\text { Arsenic } & \text { (gross } \\
\text { content),mg/kg }\end{array}$ & $<0,05$ & $<0,05$ & $<0,05$ & $<0,5$ & \\
\hline $\begin{array}{l}\text { Molybdenum (grosscon- } \\
\text { tent), } \mathrm{mg} / \mathrm{kg}\end{array}$ & 0,01 & 0,01 & $<0,01$ & $<1$ & \\
\hline $\begin{array}{l}\text { Mercury (gross content), } \\
\mathrm{mg} / \mathrm{kg}\end{array}$ & $<0,05$ & $<0,05$ & $<0,05$ & $<0,2$ & \\
\hline $\begin{array}{l}\text { Cadmium } \\
\text { content),mg/kg }\end{array}$ & $<0,05$ & $<0,05$ & $<0,05$ & $<0,5$ & \\
\hline $\begin{array}{l}\text { Fluorine } \\
\text { content),mg/kg }\end{array}$ & $<1$ & $<1$ & $<1$ & $<1$ & \\
\hline Hydrogen index, unitpH & 7,4 & 7,7 & 8,2 & 7,4 & - \\
\hline $\begin{array}{l}\text { Petroleumproducts, } \\
\mathrm{mg} / \mathrm{dm}\end{array}$ & 0,11 & $<0,05$ & $<0,05$ & $<0,05$ & \\
\hline
\end{tabular}


Significant typical impact factors in the developed hierarchical structure for monitoring were classified and the main cause-and-effect relationships are identified for the further assessment of environmental and socio-economic consequences, taking into consideration the weight of each factor and the parametric dependencies of subcriteria for each factor for a comparative assessment of alternative options. A method of systematic analysis of the socio-economic consequences of the use of agents for the maintenance of roads for accident-free road transport infrastructure and the safe life of society has been developed [4].

\section{Conclusion}

The system analysis of heuristic and computational tools for formalization of heterogeneous data and knowledge of the intellectual information system for multi-factor ecological, social and economic assessment and monitoring of the effects of waste from year-round maintenance of roads on economic facilities and the environment was carried out. Based on the analysis of the existing regulatory framework to monitor the impact on the environment in the process year around maintenance of roads it isjustified the placement of the observation points depending on the road type, conditions of its placement, the factors that require thickening the number of observation points, an updated list of controlled pollutants on components of the natural environment, the recommended frequency of sampling in maintenance of roads of different categories.

\section{Aknowledgement}

This study was carried out in the framework of the grant RFBR № 18-29-2415.

\section{References}

[1] Glushko AN. Problem-oriented CALS-system of computer quality management of chemical deicing materials and road impregnation [Doctoral Dissertation]. Ivanovo, Russia, Ivanovo State University of Chemistry and Technology; 2013.

[2] Trynkina LV, Zabolotnaya EV, Trohin VE, Bassarabov AM Automated CALS-system for chromatographic methods of analysis in the technology of high-purity substances. Advances in Chemistry and Chemical Technology.2017;31(189):19-21. 
[3] Bessarabov, Arkadiy \& Stepanova, Tatiana \& Zaremba, Galina \& Poluboiarinova, Ekaterina. CALS-based computer-aided support in the chemical industry. ChemicalEngineeringTransactions. 2016;52:97-102.

[4] Bessarabov, Arkadiy \& Zhdanovich, O. \& Yaroshenko, A. \& Zaikov, G. Development of a database of analytical instruments for CALS-system of computer quality management for chemical reagents and high-purity substances. Industrial ACS and Controllers. 2011;11:45-56. 